\title{
Lin Foxball
}

\section{Social Control, Roman Power and Greek Politics in the World of Plutarch"}

\section{Introduction}

The writings of Plutarch, philosophically, rhetorically and morally charged as they are, provide vivid glimpses of the world of Greek provincial élites under Roman rule. In this paper I shall explore aspects of Plutarch's political treatises in the larger context of the civic life of Greece in the Roman period. Inscriptions reveal something of the civic titles and public benefactions of the wealthy1. Plutarch adds a more personal dimension, promoting an ethos of self-imposed social control as the best alternative for those who have more or less prospered under Rome as caretakers of municipal government.

By Plutarch's time, the cities of Greece had long been welded together within the Roman provincial organisation. However, 'Romanisation' had not been a simple process ${ }^{2}$. Across the Greek world new hierarchies of power were imposed and gradually urban-based élites were encompassed by them. Local accommodation to Roman rule had been accomplished in different ways in different places. From hellenistic through to Roman times, in contrast to the socio-political insu-

" I would like to thank David Cohen and the Historisches Kolleg Munich, especially Frau Dr Müller-Luckner. All translations of Plutarch Moralia into English are taken from D. Russell, Plutarch. Selected Essays and Dialogues (Oxford, New York 1993), unless otherwise acknowledged.

1 There is a vast literature on the epigraphical sources for cities in Roman Greece. The classic works are still A. H. M. Jones, The Greek City from Alexander to Justinian (Oxford 1940); The Cities of the Eastern Roman Provinces (Oxford 21971). See also $M$. Wörrle, Stadt und Fest im Kaiserzeitlichen Kleinasien (München 1988); M. Sartre, L'Orient romain: provinces et sociétés provinciales en Méditerranée orientale d'Auguste aux Sévères (31 av. J.-C.-235 ap. J.-C.) (Paris 1991); F. G. B. Millar, The Greek City in the Roman Period, in: The Ancient Greek City-State, ed. M. H. Hansen (Copenhagen 1993) 232-60; R. van Bremen, The Limits of Participation. Women and Civic Life in the Greek East in the Hellenistic and Roman Periods (Gieben 1996).

2 S. E. Alcock, Greece: a Landscape of Resistance?, in: Dialogues in Roman Imperialism. Power Discourse and Discrepant Experience in the Roman Empire, ed. D. J. Mattingly (JRA Supp. 23, Portsmouth, RI 1997) 103-15; Millar, Greek City (n. 1) 247-51; cf., R. Lamberton, Plutarch and the Romanizations of Athens, in: The Romanization of Athens, eds. $M . C$. Hoff, S. I. Rotroff (Oxford 1997) 151-60. 
larity of many classical polis communities, local élites had developed a wide range of regional and even international connections through friendship, patronage, and sometimes even marriage ${ }^{3}$. Greek cities continued to function internally as poleis, but the rules of engagement had changed.

\section{Plutarch's 'Rules for Politicians': viewing Roman rule from a Greek city}

Plutarch wrote several treatises which deal with contemporary, broadly political themes". These include "Whether an Old Man should be in Politics'5 and "Against Borrowing Money'6, and contemporary themes appear in parts of his other work, for example, 'Roman Questions"7 and 'The Seven Wise Men at Dinner'8. The treatise which deals most explicitly with civic life, 'Rules for Politicians", is addressed to a wealthy and well born young man from Sardis, Menemachos, who is about to launch a political civic career. Typically of Plutarch's writing, points are illustrated by an eclectic range of historical examples, citing the deeds and words of great figures of the glorious Greek and Roman pasts. Nonetheless, the framework of the treatise is firmly grounded in Plutarch's present. It thus offers an illuminating personal account of the ideals and values of Greek political life under Roman rule, covering political lifestyle, rhetoric, friendship, patronage and knowing the limits. It also complements epigraphical sources in providing information on the kinds of things politicians did in these cities.

\section{Political lifestyle}

For Plutarch, politics was a lifestyle. As portrayed in his writing, it was the lifestyle for those of wealth and good birth, ideally to be pursued not as a source of gain ("it is wrong to enter upon public life as a money-making business ..."10), but for the sake of public service after consideration and planning. "Just as people who are not happy at home spend most of their time in the agora, even if they have no call to be there, so too there are persons who throw themselves into public life

${ }^{3}$ E.g., M. Woloch, Roman Citizenship and the Athenian Elite A.D. 96-161 (Amsterdam 1973); A. J. S. Spawforth, Families at Roman Sparta and Epidauros: Some Prosopographical Notes, in: BSA 80 (1985) 191-258.

4 C. P. Jones, Plutarch and Rome (Oxford 1971) 110-21.

5 Plut. Mor. 783B-797F.

6 Plut. Mor. 827D-832A.

7 Plut. Mor. 263D-291C.

8 Plut. Mor. 146B-164D.

9 Plut. Mor. 798A-825F.

10 Plut. Rules for Politicians $798 \mathrm{E}$. 
because they have no interests worth troubling about. Their politics is their pastime. With many, again, it is chance that has led them to put their hands to public affairs; then, when they have had enough of it, they find it hard to escape."11

Moreover it was a lifestyle which permeated a man's being and lasted a lifetime. Echoing the words but updating the sense of Aristotle's 'Politics' 1,2, Plutarch maintains: "... they are mistaken who think that engaging in public affairs is like going to sea or to war, something undertaken for an object distinct from itself and ceasing when that object is attained; for engaging in public affairs is not a special service (leitourgia) which is ended when the need ends, but is a way of life of a tamed social animal living in an organised society, intended by nature to live throughout its allotted time the life of a citizen and in a manner devoted to honour and the welfare of mankind."12

In Plutarch's view, there was a complex hierarchical matrix of civic duties and behaviours. Which were appropriate for an individual depended on his ranking within the social order of the city, his wealth, and his age, life-stage and skills. So, for example, 'poor' men should not aspire to the offices and public activities of the very rich. "If your means are moderate and circumscribed, so as just to meet your needs with nothing to spare, there can be nothing mean or disgraceful in confessing your poverty and declining to take a part in the expensive displays of the wellto-do, rather than borrowing money and making a laughing stock of yourself over your public service." 13

Similarly, old men should restrict their activities to those which dignify their age and status. "But the old man in public life who undertakes subordinate services, such as the farming of taxes and the supervision of harbours and of the market-place, and who moreover, works his way into diplomatic missions and trips abroad to visit commanders and potentates, in which there is nothing indispensable or dignified, but which are merely flattery to curry favour, seem to me, my friend, a pitiable and unenviable object, and to some people, perhaps a burdensome and vulgar one. For it is not seasonable for an aged man even to be occupied in public offices, except in those which possess some grandeur or dignity, such as that which you are now administering at Athens, the presidency of the Council of the Areopagus, and by Zeus, the honour of membership in the Amphyctionic Council which your native State (patris) bestowed upon you for life ..."14

However, the order of statuses in political life was complex and not always what it seemed. Behaviours were context specific, and accrued dignity or shame according to the civic setting in which they were performed. How one held office was even more important than which offices one held. Both etiquette and strategy played important roles in the power games of office holding. ",Powers' and elective offices are not to be pursued too often or too anxiously, for love of office is

11 Plut. Rules for Politicians 798C-D.

12 Plut. Whether an Old Man should be in Politics 791C.

13 Plut. Rules for Politicians 822D; cf. Against Borrowing Money.

14 Plut. Whether an Old Man should be in Politics 794A-B. 
neither dignified nor popular. But neither are they to be rejected, if the people (demos) offers an office legally and invites you to accept it. Even offices which are beneath your position should be welcomed and made a source of pride. It is only fair that men honoured by great office should in turn lend their honour to lesser ones, and prove themselves modest enough to sacrifice some of the grandeur of such offices as the generalship at Athens, the presidency at Rhodes, or our post of boeotarch, and lend respectability and weight to positions of less importance."15

Taking a personal interest was to be encouraged. "When they reproach me with personally supervising the checking of the tiles and the delivery of cement or stones, I reply 'Well, I'm not building this for myself, but for the city'. In many other causes, of course, one would be mean and petty-minded to organise things for oneself and be one's own manager; but if it is in the public cause and for the city's sake, one does not demean oneself ..."16

However, in contrast to a considerable proportion of the surviving epigraphical evidence, Plutarch predictably takes a very moral line on benefactions and "bread and circuses'. Euergetism should not be excessive ${ }^{17}$, nor should benefactors seek excessive honours in return ${ }^{18}$. The most vulgar displays and outrageous expenditure should be avoided if possible ${ }^{19}$, or at least only provided in a limited way to indulge the masses and get them on your side ${ }^{20}$.

Further, Plutarch argues, it is an abuse of power and privilege "for the man of wealth and standing to despise a poor, uneducated (idiôtes) magistrate". It diminishes rather than enhances a rich man's prestige to be seen "insulting umpires at the games, abusing producers at the Dionysia, and ridiculing generals and gymnasiarchs". "It does greater credit to a man of great influence to be seen in attendance on a magistrate than to be attended or escorted by one." 21

Nonetheless it is clear that the wealthiest and strongest called the shots in city life, though there were not rigid divisions between rich and 'poor' (or at least the less rich). Persons from a range of statuses, at least from Plutarch's point of view, might hold office ${ }^{22}$. The politician, says Plutarch, is the "head bee"23. $\mathrm{He}$ "... should allow others to hold office, and invite them onto the platform in a kindly and generous spirit, not doing all the city's business by his own words, proposals, and actions, but by having loyal and able helpers, and assigning each his task according to his ability" 24 .

15 Plut. Rules for Politicians 813C-D.

16 Plut. Rules for Politicians 811C.

17 Plut. Rules for Politicians 822C.

18 Plut. Rules for Politicians 820A-F.

19 Plut. Rules for Politicians 818C-E; 823E.

20 Plut. Rules for Politicians 818A-B.

21 Plut. Rules for Politicians 817A-C.

22 See Plut. Rules for Politicians 816A-B.

23 Plut. Rules for Politicians 813C.

24 Plut. Rules for Politicians 812C. 


\section{Persuasion and rhetoric}

Persuasion both by word and by deed were crucial elements of Plutarch's politics. But, rhetoric in his time carried a very different significance than in earlier periods. Politicians lived their lives in front of the ancient equivalent of the popular press and as eminent men were objects of public curiosity and slander. People wanted to know all about eminent men, not just their political life, but also their dinner, sex-life, marriage and amusements ${ }^{25}$. Smooth talking persuaded 'friends' and superiors, but was particularly important for winning over the masses ${ }^{26}$, and Plutarch distinguishes carefully between the kinds of speeches appropriate in the assembly or other political settings from those appropriate to the lawcourts ${ }^{27}$. In the civic world of Plutarch, politicians were not just part of the demos and the citizen body, they were superior to it ${ }^{28}$.

\section{Friendship and patronage}

Friendship was critical to the operation of political life, and a successful politician would from the start of his career try to cultivate 'friends'. So, for example, as a young man a budding politician will attach himself (like a vine climbing a tree) to a man of power and reputation who has achieved these things by his goodness ${ }^{29}$. The importance of friendship (philia) as a political relationship is manifest in the large proportion of Plutarch's political writings dedicated to friendship and enmity (its opposite in his view) ${ }^{30}$. Much political life was based on using wealth, influence and connexions to build up the loyalty of linked circles of friends, preferably with oneself at the centre ${ }^{31}$. Some of these 'friends' might also be or become family; and the epigraphical record provides abundant evidence of families cooperating in office holding, benefaction and other political activity 32.

Friends worked together to establish the laws and pass the measure they thought best before the citizen body. Despite his disapproval of factionalism (staziasthai, see below), it is clear that Plutarch envisaged civic affairs as directed by small groups of cooperating (and competing) friends, generally the men of wealth and influence. "Many useful measures, even if they do not produce party strife or

25 Plut. Rules for Politicians 800D.

26 Plut. Rules for Politicians 801E; 802D-E.

27 Plut. Rules for Politicians 802E-803A; 803F.

28 E.g. Plut. Rules for Politicians 801E; 803F; 818A-D.

29 Plut. Rules for Politicians 806B-C.

$30 \mathrm{Cf}$. 'How to Profit from your Enemies', Plut. Mor. 86B.

${ }^{31}$ See Plut. Rules for Politicians 813A-C, quoted below.

32 E.g. van Bremen, Limits of Participation (n. 1); M.T. Boatwright, Plancia Magna of Perge: Women's Roles and Status in Asia Minor, in: Women's History and Ancient History, ed. S. B. Pomeroy (Chapel 1991) 249-72; The City Gate of Plancia Magna in Perge, in: Roman Art in Context: an Anthology, ed. E. D'Ambra (Englewood Cliffs, NJ 1993) 189-207. 
vocal opposition, are suspected of being the product of conspiracy. This greatly discredits clubs (betaireiai) and friendships (filiai).... But when the public (boi polloi) has suspicions about some important measure which will save the situation, we must not all come forward, as if by prior arrangement, to make the same proposal. Two or three of our friends should quietly separate themselves from us and oppose the item, then later claim to be convinced and change their minds. They will carry the people with them, because it will be thought that they are guided by their sense of the expedient. In small matters of little consequence, on the other hand, it is a good idea to let one's friends have genuine differences of opinion, each with his own arguments, so that their consensus for good in matters of moment and significance does not appear to have been preconcerted." 33

"Friends are the living thinking tools of the statesman." 34 So, although in theory 'friends' were equal, in fact a man of wealth and influence would use his resources and connexions both to help and to obligate his friends as part of an overall career strategy. "There are also honourable ways of giving financial help to friends in need through one's public position... Give one man a well-paid brief in a good cause; introduce another to a rich man who needs management services and legal protection; help another to get this contract or profitable lease." 35

The dividing line between friendship and patronage or dependency was mobile, fuzzy and deliberately mystified. However, political 'friends' and colleagues were clearly aware of distinctions of rank, social status and prestige ${ }^{36}$. "If people regard comradeship in the army (sustratenesthai) or as students (sunephêbusai) as a basis of friendship, but treat colleagues in the office of general or magistrate as a cause of enmity, they are bound to fall into one of three errors: if they think their colleagues are their equals, they are creating factions; if they think them their superiors, they are guilty of envy; if they think them below themselves, guilty of contempt. The right attitude is to serve your superior, advance your inferior, and honour your equal, remaining agreeable and friendly to all." 37

Simultaneously, cultivating friends of higher rank than yourself was important for helping one's own career and for the benefit of the city. The most critical friendships of this sort, two-edged as they were, were with powerful Roman offcials. "It is not enough to keep oneself and one's city blameless in the eyes of our rulers; one should always have a friend among the really powerful people up there, as a secure prop for one's policy. The Romans themselves are very keen to support their friends' political interests." 38

However, one should not be tempted to abuse relationships with powerful men among the Romans for short-term political gain against local adversaries. The price paid is likely to be the destruction of the polis and Greek political life itself.

33 Plut. Rules for Politicians 813A-C.

34 Plut. Rules for Politicians 807D.

35 Plut. Rules for Politicians 808F-809A.

36 Cf. Plut. Rules for Politicians 812C, quoted above; 817A-C, discussed above.

37 Plut. Rules for Politicians 816B.

38 Plut. Rules for Politicians 814C. 
"However in ensuring that your country is obedient to the ruling power, there is no need to chain up your neck as well. Yet some do precisely this. They refer great matters and small alike to the governor, and so make our subject-status a reproach, or rather destroy the whole basis of our political life, reducing us to cowering, frightened impotence.... The main cause of this is the greed and ambition of our leading men. Either they force lesser persons into exile by the damage they do to them, or they bring in the superior power because, in their disputes with one another, they cannot beat to take second place among their fellow citizens. In both cases council, people, courts and magistrates lose their power altogether." 39

\section{The other side of friendship}

This ideal vision of public life as public service undertaken for worthy motives (philanthropia), is, however, disrupted by the sordid realities of engaging in political discourse with (allegedly) less worthy, and certainly competing, politicians. Competition, strife, and ambition are words which appear repeatedly in 'Rules for Politicians'. Consequently, Plutarch has much to say about the evils of greed, gain, and factionalism ${ }^{40}$. Personal enmity is also highlighted as a major cause of trouble in politics. It is the subject of a whole separate treatise, 'How to Profit from your Enemies'41, and can too easily spill over from private to public life ${ }^{42}$.

Envy is singled out as a particular problem endemic in civic life ${ }^{43}$. Envy is a hazard for a young man at the outset of his career ${ }^{44}$. For old men in public life; however, envy, "the greatest evil attendant upon public life" 45 , is less of a problem, though old should let the younger men have their turn ${ }^{46}$.

\section{Concord (bomonoia) and strife and the limits of political activity}

For beekeepers, the healthiest hive is that which buzzes loudest, but for Plutarch, the hum of factionalism in a city signalled the malady of disorder and chaos ${ }^{47}$. The

39 Plut. Rules for Politicians 814E-815B.

40 E.g. Plut. Rules for Politicians 815A-B; 823F.

41 Plut. Mor. 86b-92. The treatise was addressed, to an eminent Greek from Epidauros who was also a prominent Roman official, whom Plutarch assumed was familiar with Rules for Politicians.

42 Plut. Rules for Politicians 824F-825A.

43 See Plut. Rules for Politicians 814E-815B, quoted above; 813D.

44 Plut. Rules for Politicians 804 D-E; 806C.

45 Plut. Whether an Old Man should be in Politics $787 \mathrm{C}$.

46 Plut. Whether an Old Man should be in Politics 795A; Rules for Politicians 806C.

${ }^{47}$ Plut. Rules for Politicians 823F. 
ideals of concord (homonoia) which Plutarch promotes are prominent in other Greek literature, inscriptions and coins throughout the Roman period ${ }^{48}$. Sheppard has assembled the evidence for bomonoia as a feature of relationships both between and within cities. He argues that within cities, bomonoia served as a shield of unity against the Roman authorities, but at the same time stifled political debate between the wealthy élite who ran the cities and the popular assemblies ${ }^{49}$.

Close examination of Plutarch's work suggests this may be an oversimplification, if we are to believe Plutarch's depiction of civic life, as small groups of 'friends' (and families) from a range of ranks and statuses each striving for their own interests and engaged in an almost permanent state of factional strife. Plutarch perceived the threat of factionalism as a serious problem in the face of Roman rule ${ }^{50}$ because it exposed the city to possibility of direct interference by the Roman authorities: "cities where total confusion reigns [as a result of factionalism] are utterly ruined, unless forcibly brought to their senses by disaster, through some external compulsion or chastisement." 51 This was not, of course, in the best interests of the élites who ran the cities in their own interests. Homonoia, therefore, was not just a veneer of political claptrap or a rhetorical ideal. It was more like a one way mirror: a public presentation of the city as a united community of citizens and magistrates facing the external perspective of the Roman rulers. Viewed from the other direction, however, the factional elements within cities, wealthy individuals and families striving for local control and eminence, are clearly visible. Moreover, Plutarch's stress on concord and the evils of factionalism might well imply that the latter was an endemic problem.

Hence, for Plutarch, one of the most important jobs of the man active in civic life was to prevent stasis, "this is the greatest and noblest part of the art of statesmanship"52. Echoing, but not replicating Aristotle ${ }^{53}$, he lists the megista agatha for cities as peace, freedom, plenty, population and concord ${ }^{54}$. But, these concepts took on new meanings under the rule of Rome. Plenty and population a prudent (sophron) man will request from the gods for his fellow citizens. However, "for peace our peoples ( hoi demoi) have no need of politicians at present; every Greek war, every foreign war has passed away from us. As to freedom, the people have as much as the ruling power allows; and it is perhaps best that they should have no

48 S. Swain, Plutarch's Moral Program, in: Plutarch's Advice to the Bride and Groom and A Consolation to his Wife, ed. S. B. Pomeroy (New York, Oxford 1999) 87-9; $A . R . R$. Sheppard, Homonoia in the Greek Cities of the Roman Empire, in: Ancient Society 15-17 (1984-6) 229-52.

49 Sheppard, Homonoia (n. 48) 246-8.

50 Plut. Rules for Politicians 815A, quoted above.

51 Plut. Rules for Politicians 824A-B.

52 Plut. Rules for Politicians 824B-C.

${ }^{53} \mathrm{Cf}$. Arist. Rhet. 1359b-1362a on important subjects for deliberation regarding the city and happiness (eudaimonia) for individuals and cities. Among Aristotle's concerns paralleled by those of Plutarch are the defence of the city, wealth and plenty, population, honour and honourable descent. Significantly absent are freedom and concord.

54 Eirene, eleutheria, euteria, euandria, bomonoia, Plut. Rules for Politicians 824C. 
more". In other words, the two political functions of war/peace ${ }^{55}$ and freedom/ autonomy were no longer in the control of Greek cities and it had become dangerous to meddle with them. This is underpinned by the elevated importance of the only one of these activities left to the politician: "to ensure perpetual concord (bomonoia) and friendship (philia) among one's fellows, and the removal of all kinds of strife, dissension and hostility"56. For a man of wealth and influence engaged in the local politics of Greek cities under Roman rule, this represented the course of prudence. It ensured that the eyes of Rome were not drawn to a trouble spot, and maintained maximum freedom for individual manoeuvre in political activity. In this sense, bomonoia is more a negative than a positive virtue: an ideal which highlights that the most important common interest of competing individuals, families and groups within a Greek city was avoiding Roman interference in internal affairs, for if that happened everyone lost and no one gained ${ }^{57}$.

Plutarch freely acknowledges recognises that all the competition and striving for honour and glory within the city is petty and insignificant, for Greek affairs are weak ${ }^{58}$ and Rome has the ultimate power: "fortune has left us no other prize to fight for. What power, what glory can the victor expect? What influence (dynamis) is this, that a short pronouncement from the proconsul suppresses or transfers to another? Even if you keep it there is nothing there worth the trouble." 59 Ultimately, the boots of Roman hegemony are visible over the crown of office and one cannot invest pride or trust in such a crown ${ }^{60}$.

\section{Civic activity and citizenship}

Within the confines of Roman rule, the activities of politicians were limited. Foremost among those mentioned by Plutarch are serving on embassies, especially to put requests to Roman officials, lawsuits and legal activity, public speaking in the assembly and on other occasions, and office holding. The first two jobs are mentioned as particularly suited to men of high standing ${ }^{61}$. It is difficult to be certain about whether the legal activity to which Plutarch refers relates to Roman law and courts, or local judicial structures operating within the city state, encompassed by Roman law but somewhat disarticulated from it.

Sheppard notes that Plutarch ignores the fact that some members of the wealthy élite would also have been Roman citizens, settling their disputes to Roman under

55 In effect, foreign policy, cf. Plut. Rules for Politicians 805A and Arist. Rhet. 1359b-1360a.

56 Plut. Rules for Politicians 824D.

57 Cf., Plut. Rules for Politicians 814E-815B, quoted above and 824F-825A.

58 Plut. Rules for Politicians 824E.

59 Plut. Rules for Politicians 824E-F.

60 Plut. Rules for Politicians 813F.

61 Plut. Rules for Politicians 805A-B. Plutarch mentions these activities as the kind of subjects which eminent men at dinner like to discuss, since they have a chance to show off their successes Plut. Quaest. conviv. 2, Mor. 630E-631A. 
Roman law ${ }^{62}$. However, a striking feature of Plutarch's political treatises is that civic life is portrayed as entirely the outcome of Greek polis citizenship. Despite the fact that he himself was a Roman citizen, and though he places great emphasis on creating and maintaining proper relationships with the Roman authorities, Plutarch says nothing about Roman citizenship, treating it as if it were irrelevant to Greek civic and political life. This might be because for the most part Roman authority was genuinely irrelevant to the inner workings of poleis, which sometimes still portrayed themselves as if they were "democratic"63. The titles which magistrates held, the local forms of governing bodies (e.g. councils, assemblies, etc.), many civic religious activities were framed in 'traditional' Greek terms, even if they were not altogether ancient in origin ${ }^{64}$. Individuals who were Roman citizens did not always use their full Roman names in inscriptions but used their Greek names exclusively, or included them in addition to their Roman names ${ }^{65}$. The question of whether Greek cities kept their own laws and customs where they did not impinge on Roman authority is more difficult (see below). This is probably a further manifestation of the Janus-faced stance of these cities and élites who ran them. Their internal 'autonomy' was most effectively preserved by presenting themselves to Roman authority as a self-contained and effective, if somewhat alien, political order which if left untampered would serve them well. If a united front, a smooth surface, could be maintained, the competition of local élites for local power could continue on the other side of the glass beyond the notice of the Roman rulers. Significantly, one of the 'jobs' Plutarch specifically earmarks for 'politicians' is to act as envoys to Roman officials on behalf of their native cities, and he describes his own experience as an envoy to the proconsul66. For such tasks Greek politicians who were also Roman citizens might have served their own cities particularly well67.

For Plutarch, civic life and political discourse is a fully masculine preserve. In his accounts of political life, women have no place in political activity, not even in public service to the city. This is a notable contrast to the considerable number of inscriptions which document women's civic benefactions and office holding, on their own or jointly with their husbands or other members of their families. It might also appear to contrast with Plutarch's reputation for holding women in high esteem ${ }^{68}$, and his celebration of marriage and family. It is hard to know how

62 Sheppard, Homonoia 241 (n. 48).

63 Cf. Plut. Rules for Politicians 816F.

64 With the obvious exception of imperial cult.

${ }^{65}$ E.g. C. P. Jones, A Leading Family of Roman Thespiae, in: HSCP 74 (1970) 223-55; Spawforth, Families at Roman Sparta and Epidauros (n. 3).

66 Plut. Rules for Politicians 816D.

67 In Plutarch's time relatively few Greeks bore Roman citizenship compared to the much larger number of Roman citizens in the western provinces, see $P$. Brunt, The Romanization of the Local Ruling Classes in the Roman Empire, in: Assimilation et résistance à la culture grèco-romaine dans le monde ancien, ed. D. M. Pippidi (VI Cong. Int. d'Et. Cl., Paris 1976) 161-2.

${ }^{68}$ A. G. Nikolaides, Plutarch on Women and Marriage, in: WSt. 110 (1997) 27-88; C. Patter- 
to read this apparent contradiction. I have argued elsewhere that Plutarch most esteems women in their place, which is under the firm control of men ${ }^{69}$. It may also be an idealised, and to some extent archaising, aspect of his discourse on public life which leaves it to 'real men' and cut out women whether they were in fact there or not. However, women are very unlikely to have been directly involved in many of the activities of politicians on which he dwells (lawsuits, embassies, public speaking etc.). The aspect of civic life in which women are most clearly documented in the epigraphical record, euergetism, is also, perhaps not coincidentally, one which Plutarch considers morally ambivalent.

\section{Roman law and Greek custom?}

Much harder is the question of interfaces between Roman law and Greek custom and local legal systems. It is apparent in the 'Roman Questions'70 that even after several generations of Roman rule Plutarch (and presumably other Greeks) still viewed Roman culture and custom as alien. Of the 113 questions, most deal with matters of religion (52 - significantly none deal with imperial cult) and 'ancient' history (43), typical concerns of Plutarch. However some of the questions clearly belong in the time of Plutarch, and attempt to explain elements of Roman culture which are odd to Greek eyes. Of these, a striking 25 deal with marriage and family customs, 15 with custom more generally and 7 with the peculiarities of the Roman calendar (see table 1).

Plutarch portrays Roman notions of kinship and behaviour towards kin (both agnates and affines) as particularly odd to Greeks. For example, question 108: 'why don't they marry women who are close kin?'71, is also addressed at the end of question $6^{72}$. The answer to question 108 is framed in terms comprehensible for Greek social structures (did they wish to enlarge their sphere of kin, were they worried about intra-familial quarrels and did they wish to expand the number of potential protectors for vulnerable women). However, it misses the point that Romans of Italian origin considered marriage between close kin to be incestuous. By Plutarch's time, marriage between cousins, a normal and ancient Greek practice, had become more regular in Roman society, perhaps partly under the influence of Greek and other provincial customs, and certainly for financial reasons (i.e. keeping the property in the family $)^{73}$. In question 6 Plutarch notes that in his time

son, Plutarch's Advice to the Bride and Groom: Traditional Wisdom through a Philosophical Lens, in: Pomeroy, Plutarch's Advice (n. 48) 128-37.

69 L. Foxhall, Foreign Powers: Plutarch and Discourses of Domination in Roman Greece, in: Pomeroy, Plutarch's Advice (n. 48) 139, 145-50.

70 Plut. Mor. 263D-291C.

71 Plut. Mor. 289D-E.

72 Plut. Mor. 265D-E.

73 S. Treggiari, Roman Marriage (Oxford 1991) 37-9; S. Dixon, The Roman Family (Baltim- 
Roman men would marry their cousins but not their aunts or sisters. Also, law and custom varied widely across the Roman empire, so for example brother-sister marriage, regularly practised in Egypt, or the levirate of Jewish law, would not have been considered acceptable in other parts of the Roman world ${ }^{74}$. Nonetheless, despite the cosmopolitan nature of the upper eschelons of polis society, other traditions of construing marriage and family are portrayed as alien.

The aetiological story he tells to explain how the marriage to cousins became permitted among the Romans is again framed in Greek not Roman terms, focusing on a man who married his cousin, an epikleros ${ }^{75}$. The notion of the epikleros, a woman without father or brothers living, was meaningless in Roman law where women could inherit property in their own right, but crucial to Greek ideas of marriage and inheritance of property (where most important forms of wealth ideally travelled through agnates).

I have argued elsewhere that the notion of the epikleros appears in the 'Erotikos', and that the roles of the characters in socio-legal terms are consistent with their actions in the dialogue ${ }^{76}$. The mother of Ismeodora's young beloved, Bacchon was most likely an epikleros in Greek terms, perhaps also the widow Ismenodora herself, however they might have been legally construed in Roman terms ${ }^{77}$. Anthemion, an older relative of Bacchon, who advocates his marriage with Ismenodora, appears to be acting as a guardian for him. The dialogue is a kind of philosophical Menandrian comedy in prose, and it would be a mistake to take it too literally and rash to assume that it reflects contemporary 'real life' in any way directly. However, if the notion of the epikleros is central to the plot, this does suggest that the concept still had some social meaning for Greeks whatever its legal validity might have been. Indeed, its legal validity might have varied depending on the statuses of those involved in any particular situation, and the particular arena in which it arose as an issue.

The main issue of 'Roman Questions' 678: "why do women kiss their relatives on the mouth?" provides another interesting example. In question 108 the issue was a custom which Greeks found normal but was not part of Roman tradition. This one is just the opposite: a custom which Greeks would have found unfamiliar and even shocking, but which was normal to Romans. Plutarch suggests that the custom might have been granted as a privilege to women, and that it might have been relates to the issue of permitted marriage partners. But, rather than attempting to explain the custom, Plutarch almost excuses it by relating two aetiological stories about detecting women who had drunk wine and the Trojan women land-

ore 1992) 82, 91. On the frequency of marriages between close kin in Greek cities in Roman times see van Bremen, Limits of Participation (n. 1) 257-61.

${ }^{74}$ K. Hopkins, Brother-Sister Marriage in Roman Egypt, in: CSSH 22 (1980) 303-54.

75 Plut. Mor. 265D-E.

76 Plut. Mor. 748F-771E. Foxhall, Foreign Powers (n. 70).

77 It is not clear from the work, and is not relevant to the plot, whether or not they were Roman citizens.

78 Plut. Mor. 265B-E. 
ing in Italy who burned the boats behind them. The peculiarity of the custom, to Greek eyes, rendered it incomprehensible.

The depiction of Roman custom as alien, in conjunction with loyalty to Greek 'traditions' may have been a conscious attempt on the part of élite Greeks to distance themselves from the culture of foreign oppressors. Upholding their own 'ancient traditions' could serve as a way of asserting their cultural superiority and expressing cultural resistance which was not perceived by the Romans in the negative way that political resistance would have been. Perhaps the lack of reference to imperial cult in the political treatises or in the 'Roman Questions' is significant in this regard. Simultaneously, it seems probable that many elements of Roman culture remained foreign because the Greeks really had stuck to their own traditions and customs within city life. The big question is the extent to which local Greek customs served as a basis for local law in the cities of Roman Greece, and the surviving evidence is inadequate to answer it definitively ${ }^{79}$. The realm of law is a critical interface between culture and politics, particularly in the areas of family and property which straddle public and private interests. Perhaps it is not coincidental that Plutarch was so concerned with marriage and family custom in the 'Roman Questions': these are areas where Greeks who were also Roman citizens could be regularly crossing the boundaries between Roman law and Greek custom in everyday life. Certainly the Roman legal framework appears to fit quite uncomfortably around some Greek socio-legal practices.

\section{Conclusion}

Social control in the cities of Roman Greece was incorporated in a set of hierarchal relationships of power. Yet even in the face of imperial rule social control was not straightforward. Plutarch's work reveals a world in which Roman authorities controlled Greek cities by metaphorically giving their wealthy élites enough rope to hang themselves. As long as everything ran smoothly, the Romans were prepared to leave most of their internal affairs to local élites. The rivalry and factionalism rife within Greek cities focused largely on local issues, and was the product of competition between wealthy individuals and families. Rather than stifling political debate as Sheppard argues ${ }^{80}$, élites appear to have engaged in vigorous political struggles among themselves and enlisted other groups in these struggles (hence Plutarch's paranoia about the dangers of this practice). They may have encouraged

79 The subject has been much discussed in the scholarly literature from L. Mitteis, Reichsrecht und Volksrecht in den östlichen Provinzen des römischen Kaiserreichs (Leipzig 1891). See also $H$. Galsterer, Roman Law in the Provinces: Some Problems of Transmission, in: L'impero romano e le struttore economiche e sociali delle province, ed. $M$. Crawford (1986); Sheppard, Homonoia (n. 48) 241 n. 92; J. Triantaphyllopoulos, Le droit romain dans le monde grec, in: JJP 21 (1991) 76-85; van Bremen, Limits of Participation (n. 1) 225-36.

80 Sheppard, Homonoia (n. 48). 


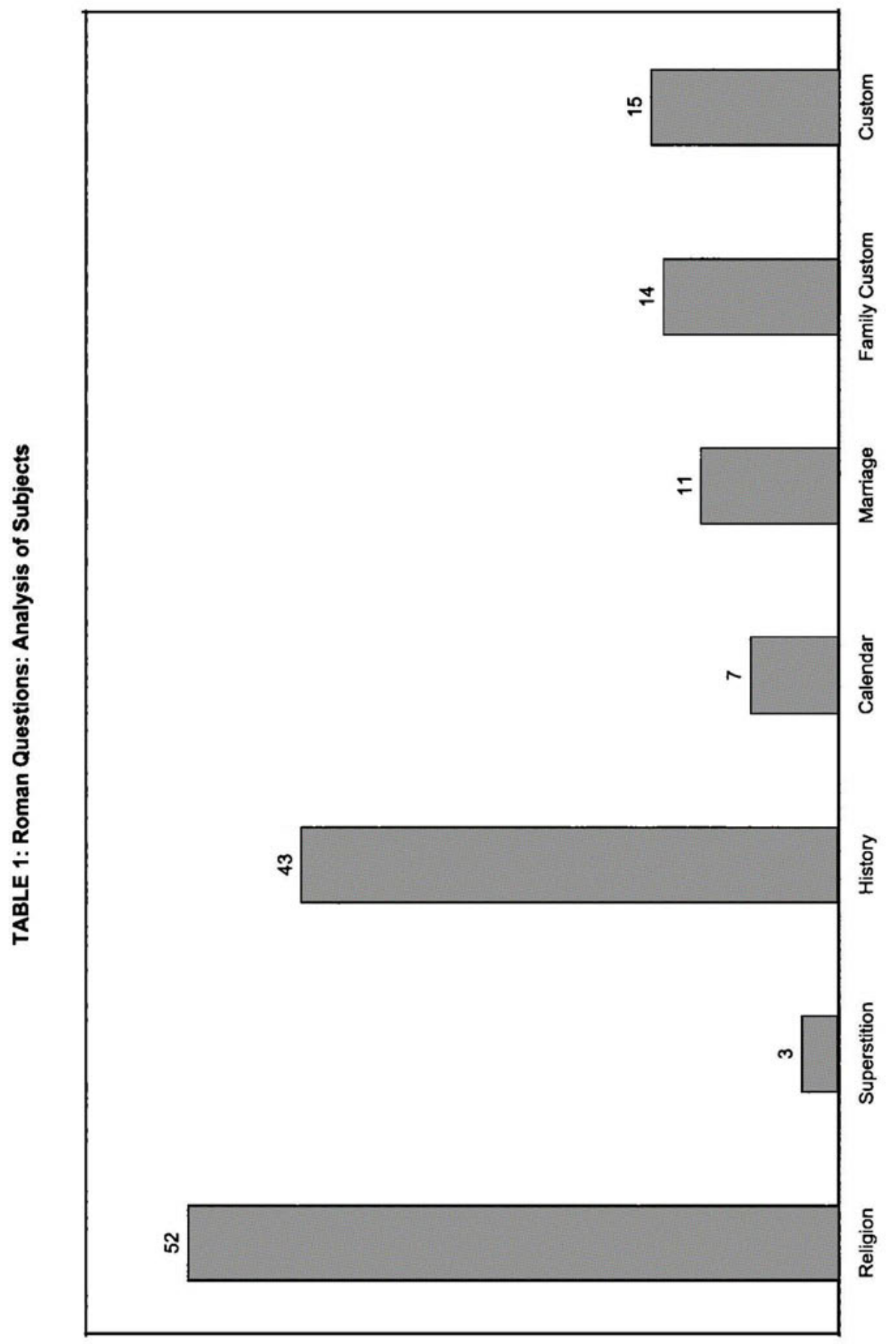


TABLE 1: Roman Questions: Analysis of Subjects

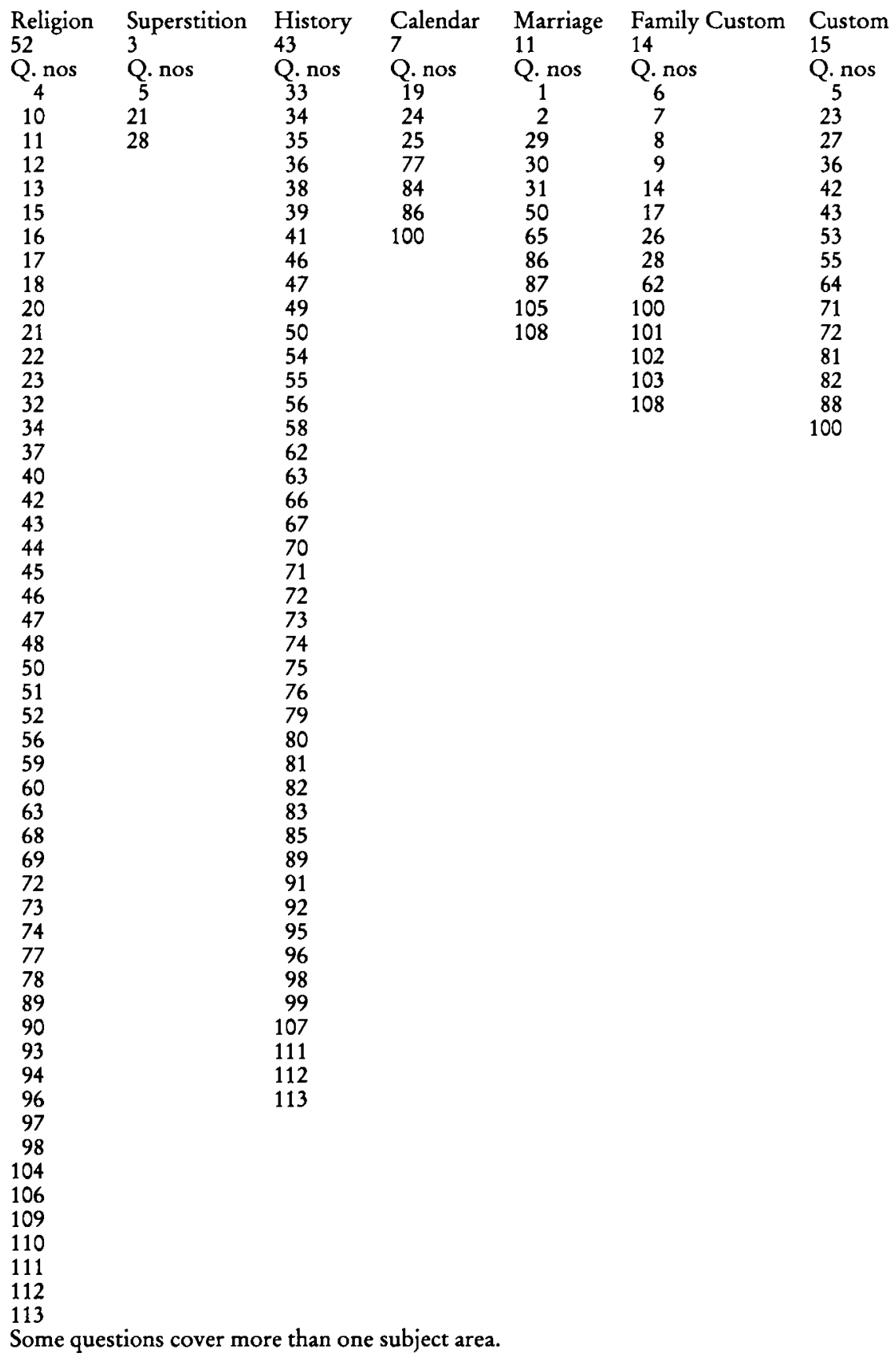


the retention of Greek social and legal traditions as a form of popular resistance to Roman rule. This might have been favoured by non-élites, but proved relatively harmless in terms of relations with the Romans. There may also have been significant differences between the cities of 'old Greece' and the more recently hellenised cities of Asia Minor in this regard, drawing as they did on quite different pre-Roman social and legal traditions. Such differences might perhaps partially explain Plutarch's neglect of imperial cult in his writings, despite his interest in the religious life of his own times.

However, it was critical that élite rivalry did not get out of hand to the detriment of civil order. However much competition developed between different factions, their ultimate interests were better served by presenting a united front of orderliness and harmony to the Roman authorities, than by trying out-compete other factions by appealing to less wealthy and less contented groups. On the other hand, allowing social discontent to get out of hand, for example by over-exploitation of the poor, might also draw the eye of the Roman authorities towards the city, with unpleasant consequences for its eminent politicians. The publicly expressed ideal of homonoia sent the right message to the Romans, presenting them with a superficially united and harmonious image of a city. Nonetheless, Greeks still endeavoured to retain their social identity as Greeks, accommodating Roman rule by defining Roman culture as alien, and simultaneously re-defining politics and civic life in new ways with a limited scope.

The realm of women's behaviour, the family and marriage was particularly well suited to manipulation by Greeks living in a Roman world. Falling as it did between social custom and law, the use of local 'Greek' conventions served as a marker of Greek identity. However, families and individuals could have negotiated the gaps between local 'Greek' and Roman practice to their own advantage, depending upon the circumstances. So, Rome does not appear to have outlawed endogamous marriage with close kin, which encouraged the consolidation of wealth in limited family groups. On the other hand, individuals with Roman citizenship must have ensured that it was passed on to their children via Roman legal practice. Perhaps this liminal position of domestic relationships, between public and private spheres and Greek and Roman identities, provides a small part of the explanation for the changed and enhanced significance of marriage and the family in the cities of Roman Greece (though the issue is complex and much discussed). What is certainly clear is that accommodating Roman rule had a major impact on the processes of social control within Greek cities. The writings of Plutarch offer a personal, though certainly not impartial, view of these processes. 